\title{
Exposure to DNA is insufficient for in vitro transgenesis of live bovine sperm and embryos
}

\author{
Shahin Eghbalsaied ${ }^{1,3}$, Kamran Ghaedi ${ }^{2}$, Götz Laible ${ }^{3}$, Sayed Morteza Hosseini ${ }^{4}$, \\ Mohsen Forouzanfar ${ }^{5}$, Mehdi Hajian ${ }^{4}$, Fleur Oback ${ }^{3}$, Mohammad H Nasr-Esfahani $^{4}$ and \\ Björn Oback ${ }^{3}$
}

${ }^{1}$ Young Researchers Club, Khorasgan Branch, Islamic Azad University, Isfahan, Iran, ${ }^{2}$ Biology Department, School of Sciences, University of Isfahan, Isfahan, Iran, ${ }^{3}$ AgResearch Ltd., Ruakura Research Centre, Reproductive Technologies, Hamilton, New Zealand, ${ }^{4}$ Department of Reproduction and Development, Royan Institute for Animal Biotechnology, ACECR, Reproductive Biomedicine Center, Isfahan, Iran and ${ }^{5}$ Biology Department, School of Sciences, Marvdasht Branch, Islamic Azad University, Marvdasht, Iran

Correspondence should be addressed to B Oback; Email: bjorn.oback@agresearch.co.nz M H Nasr-Esfahani; Email: mh.nasr-esfahani@royaninstitute.org

\begin{abstract}
Transgenic mammals have been produced using sperm as vectors for exogenous DNA (sperm-mediated gene transfer (SMGT)) in combination with artificial insemination. Our study evaluated whether SMGT could also be achieved in combination with IVF to efficiently produce transgenic bovine embryos. We assessed binding and uptake of fluorescently labelled plasmids into sperm in the presence of different concentrations of dimethyl sulphoxide or lipofectamine. Live motile sperm displayed a characteristic punctuate fluorescence pattern across their entire surface, while uniform postacrosomal fluorescence was only apparent in dead sperm. Association with sperm or lipofection reagent protected exogenous DNA from DNase I digestion. Following IVF, presence and expression of episomal and non-episomal green fluorescent protein (GFP)-reporter plasmids was monitored in oocytes and embryos. We found no evidence of intracellular plasmid uptake and none of the resulting zygotes $(n=96)$ and blastocysts were GFP positive by fluorescence microscopy or genomic PCR $(n=751)$. When individual zona-free oocytes were matured, fertilised and continuously cultured in the presence of episomal reporter plasmids until the blastocyst stage, most embryos $(38 / 68=56 \%)$ were associated with the exogenous DNA. Using anti-GFP immunocytochemistry $(n=48)$ or GFP fluorescence $(n=94)$, no GFP expression was detected in blastocysts. By contrast, ICSI resulted in $18 \%$ of embryos expressing the GFP reporter. In summary, exposure to DNA was an inefficient technique to produce transgenic bovine sperm or blastocysts in vitro.

Reproduction (2013) 145 97-108
\end{abstract}

\section{Introduction}

The ability of mammalian spermatozoa to bind exogenous DNA and transfer it to the oocyte after fertilisation in utero was first demonstrated in rabbits in 1971 (Brackett et al. 1971). Using sperm-mediated gene transfer (SMGT) in combination with IVF (SMGT-IVF), efficient production of transgenic mice was subsequently reported in 1989 (Lavitrano et al. 1989). Since then, various contradictory reports on applying this technique to livestock were published (Gandolfi et al. 1996, Garcia-Vazquez et al. 2011). By combining SMGT with laparoscopic insemination or artificial insemination (Al; SMGT-Al), one laboratory has reported transgenic embryos and offspring in pigs (Lavitrano et al. 2002, 2003, Manzini et al. 2006). However, transgene transmission appeared to be only transient (Giovannoni et al. 2010). Efficiency and reproducibility of the technique was poor in other laboratories and species (Brinster et al. 1989, Gandolfi et al. 1996, Chan et al. 2000, Garcia-Vazquez et al. 2011, Pereyra-Bonnet et al. 2011). As a consequence, SMGT has not become a widely and routinely used method for generating transgenic animals, despite its potential for simple, low-cost, scalable transgenesis with large transgenes (Osada et al. 2005).

Several methods were tested to improve uptake of DNA into sperm. These include electroporation (Gagne et al. 1991, Rieth et al. 2000), lipofection (Bachiller et al. 1991, Hoelker et al. 2007) and magnetofection (Kim et al. 2010) as well as addition of DMSO (Kuznetsov \& Kuznetsova 1995, Li et al. 2006, Shen et al. 2006) or protamine (Alderson et al. 2006). Irrespective of the transfection method, the mode of transferring exogenous DNA from the sperm into the oocyte via fertilisation is 
not well understood. First, it is unclear whether and how sperm could internalise DNA. A number of studies have employed indirect methods to investigate this phenomenon. These include liquid scintillation counting of radioactively labelled DNA co-precipitating with sperm (Lavitrano et al. 2002, Kang et al. 2008, Kim et al. 2010), flow cytometry of sperm incubated with fluorescently labelled plasmids (Canovas et al. 2010) and genomic PCR assays after incubating sperm with DNase to destroy any non-internalised exogenous DNA (Hoelker et al. 2007, Kang et al. 2008). While these assays demonstrated association between exogenous DNA and sperm, they provide no direct evidence for DNA uptake across the plasma membrane into the sperm cytoplasm or nucleus. Few studies have addressed DNA uptake into sperm using direct visualisation, such as autoradiography (Brackett et al. 1971, Atkinson et al. 1991), wide-field (Anzar \& Buhr 2006) and confocal laser scanning epifluorescence microscopy of fluorescently labelled sperm (Bachiller et al. 1991, Chan et al. 2000) or transmission electron microscopy on thin sections (Kim et al. 2010). These studies have shown DNA binding to the sperm surface, preferentially in the postacrosomal region, but not provided conclusive evidence for its uptake into sperm with an intact plasma membrane. Secondly, the potential of sperm to transfer DNA into the oocyte upon fertilisation remains to be demonstrated. A study directly addressing this by confocal microscopy showed that fluorescently labelled DNA transferred to the oocyte plasma membrane but not the oocytoplasm following sperm fusion, suggesting that the DNA was not internalised but bound to the sperm surface (Chan et al. 2000). Thirdly, detection of exogenous DNA in embryos after SMGT remains controversial. Many studies have relied on indirect genomic PCR assays that may demonstrate the presence of an exogenous DNA sequence in the embryo or surrounding culture medium but not cellular uptake of this sequence (Rieth et al. 2000, Kim et al. 2010). Cellular expression of different reporter proteins at various embryonic stages has been analysed. However, conclusive images showing expected sub-cellular localisation of the reporter accompanied by normalised signal quantification have not been reported (Webster et al. 2005). Furthermore, crucial controls to account for non-specific auto-fluorescence from green fluorescent protein (GFP)-based reporters and its variants in non- and mock-transfected embryos were often lacking (Anzar \& Buhr 2006, Hoelker et al. 2007).

By contrast, transgenesis can readily be achieved by sperm that have been co-incubated with exogenous DNA via ICSI (SMGT-ICSI). This route circumvents membrane fusion and therefore does not rely on sperm internalising exogenous DNA. It results in conclusive DNA uptake and reproducible reporter gene expression in transgenic embryos and animals (Perry et al. 1999, Chan et al. 2000, Lai et al. 2001, Pereyra-Bonnet et al.
2008, Garcia-Vazquez et al. 2009, Wu et al. 2009, Shadanloo et al. 2010).

Numerous plasmid-based DNA vector systems have been used for SMGT, most of them relying on chromosomal integration for transgenesis. A safe alternative is the use of non-viral, non-integrating episomal plasmids such as pEpi (Jenke et al. 2004b). Owing to the presence of a human scaffold/matrix attachment region (S/MAR), these vectors are stably maintained as an episomal entity in mammalian cell lines and primary cultures (Jenke et al. 2004a). Using $\mathrm{pEpi}$, the generation of transgenic pigs via SMGT-AI has been reported (Manzini et al. 2006). Here, we tested the suitability of $\mathrm{pEpi}$ and conventional non-episomal reporter plasmids for bovine SMGT-IVF, using SMGTICSI embryos as a positive control. Using a novel chemically defined, cumulus- and zona pellucida-free culture system for SMGT-IVF, we demonstrate DNA association with sperm and embryos but no evidence of transgenic blastocysts. We conclude that spontaneous DNA uptake into live sperm or embryos is exceedingly rare, severely restricting the practicality of SMGT for bovine transgenesis in vitro.

\section{Results}

\section{Live sperm bind labelled DNA and exclude non-specific uptake of label}

We first determined the interaction between exogenous DNA and capacitated sperm. Fluorescently labelled reporter plasmids were co-incubated with live (motile) or dead (frozen/thawed) sperm. Independent of the plasmid used, this resulted in three different staining patterns (Fig. 1). Live sperm showed discrete fluorescent dots or larger clusters that were randomly distributed over the entire sperm surface (Fig. 1A). Dead sperm displayed similar punctuate staining but, in addition, also showed a uniform fluorescent signal, mainly in the postacrosomal region (Fig. 1B and C). While the majority of live sperm associated with discrete dots $(282 / 304=93 \%)$, uniform postacrosomal fluorescence was almost completely absent from this group $(2 / 304=0.7 \%$ uniform and $11 / 304=3.6 \%$ mixed stain). In contrast, all dead sperm showed uniform postacrosomal fluorescence and most of those $(149 / 157=95 \%)$ also displayed dots (Fig. 1D). We conclude that a homogenous postacrosomal staining pattern indicates non-specific fluorescence signal uptake in dead sperm that is excluded from live sperm.

\section{Sperm and lipofectamine association protects exogen- ous DNA from DNase}

We next investigated whether the observed fluorescent signal originated from labelled exogenous DNA bound to the sperm surface or from internalised DNA. For this, 

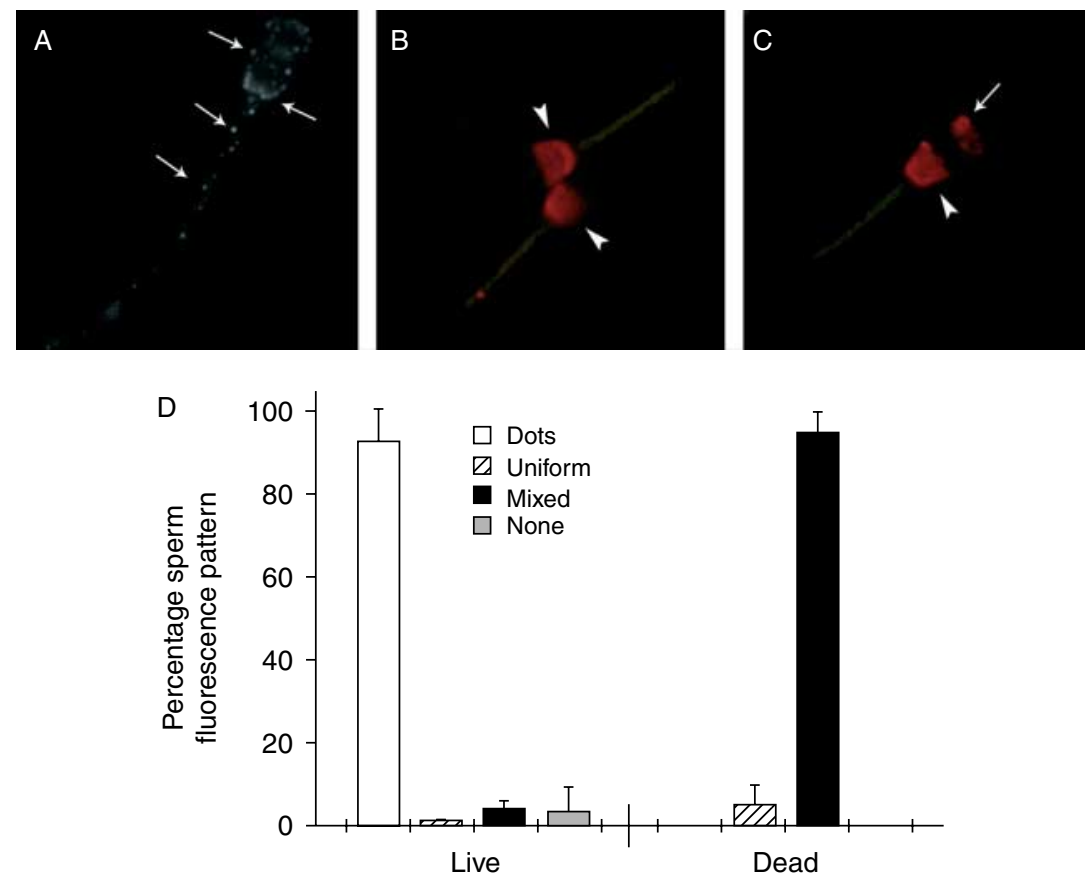

Figure 1 Binding of fluorescently labelled DNA to
sperm. (A) Live motile sperm were incubated with
Cy3-pEpi. (B and C) Dead (frozen/thawed) sperm
were incubated with rhodamine-pGeneGrip-lacZ.
Observed staining patterns were categorised into
(A) discrete fluorescent dots (arrows), (B) uniform
postacrosomal fluorescence (arrowheads) or (C) a
mix of both (arrows and arrowheads). Non-specific
green auto-fluorescence of the mid-piece is also
visible (B and C). Mean percentage ( \pm s.D.) of
different fluorescent patterns in dead frozen/thawed
vs motile sperm with three replicate
experiments (D).

we conducted DNase protection assays. Sperm were transfected with fluorescently labelled DNA in the absence (DM0) or presence of DMSO (DM1 and DM3) or lipofectamine (LP1 and LP3). While most motile sperm from all groups displayed fluorescent dots, uniform postacrosomal staining was only visible in a minority (Fig. 2A). Following DNase incubation, fluorescent dots largely disappeared from sperm but the homogenous postacrosomal fluorescent signal persisted (Fig. 2B). As postacrosomal stain was only observed in dead sperm, which are unable to fertilise during IVF and transmit the transgene, this group was excluded from quantification. Only sperm with randomly distributed discrete fluorescent dots were categorised as live, carrying DNA and quantified (Fig. 2C). Within this group, untreated (DM0) and DMSO-treated sperm (DM1 and DM3) transfected better than lipofectamine-treated sperm (LP1 and LP3). Following DNase digestion, a significant proportion of untreated and DMSO-treated sperm lost their fluorescent signal (92\% before vs 34\% after DNase, 92 vs 44\% and 93 vs 47\% for DM0, DM1 and DM3 respectively). No significant change in fluorescent signal was observed in the lipofectamine groups (64\% before vs 74\% after DNase and 29 vs $37 \%$ for LP1 and LP3 respectively), indicating that the spermassociated DNA was protected from DNase digestion. The highest proportion of DNase-resistant plasmid was present in the DM3 and LP1 groups, which did not differ significantly (51 and $74 \%$ respectively).

To validate the use of fluorescently labelled plasmids as marker for DNA-sperm interaction, we performed an independent assay. Transfected sperm were centrifuged and the pellet and supernatant subjected to semiquantitative PCR against the reporter plasmid. Plasmid
DNA was detectable in both supernatant and sperm pellet (Fig. 2D). Following DNase incubation, there was no or reduced target amplification, indicative of reduced amounts of plasmid DNA, in untreated and DMSO-treated samples, but not in any of the lipofectamine-treated samples (Fig. 2D). This suggests that DNA is protected from digestion through association with sperm and/or lipofectamine, precluding accurate quantification of DNA uptake using the DNase assay.

\section{No evidence of DNA uptake into embryos fertilised with DNA-associated sperm}

After establishing the most effective conditions for producing sperm carrying fluorescently labelled and DNase-resistant plasmid, we evaluated their effect on in vitro bovine embryo production. Sperm were incubated with either pEpi or pMax-GFP under DM3, LP1 or combined DM3/LP1 conditions and used for IVF. Irrespective of the vector, cleavage into 2-cell was reduced in the presence of lipofectamine (Table 1 ). Accounting for the lower cleavage rate, development into blastocysts was no longer reduced for pMax-GFP but still lower for pEpi (63.3 vs 48.9\%). For both plasmids, a reduction in blastocyst development was observed in the presence of DMSO (DM3).

Following fertilisation, zygotes and culture media were analysed by PCR using the DNase protection assay. Analysis of the media demonstrated the presence of contaminating carry-over DNA that was sensitive to DNase digestion with the target sequence no longer detectable after treatment. PCR with zygotes derived from IVF with DNA-incubated sperm that were DNase treated to remove any DNA attached to the outside of the 

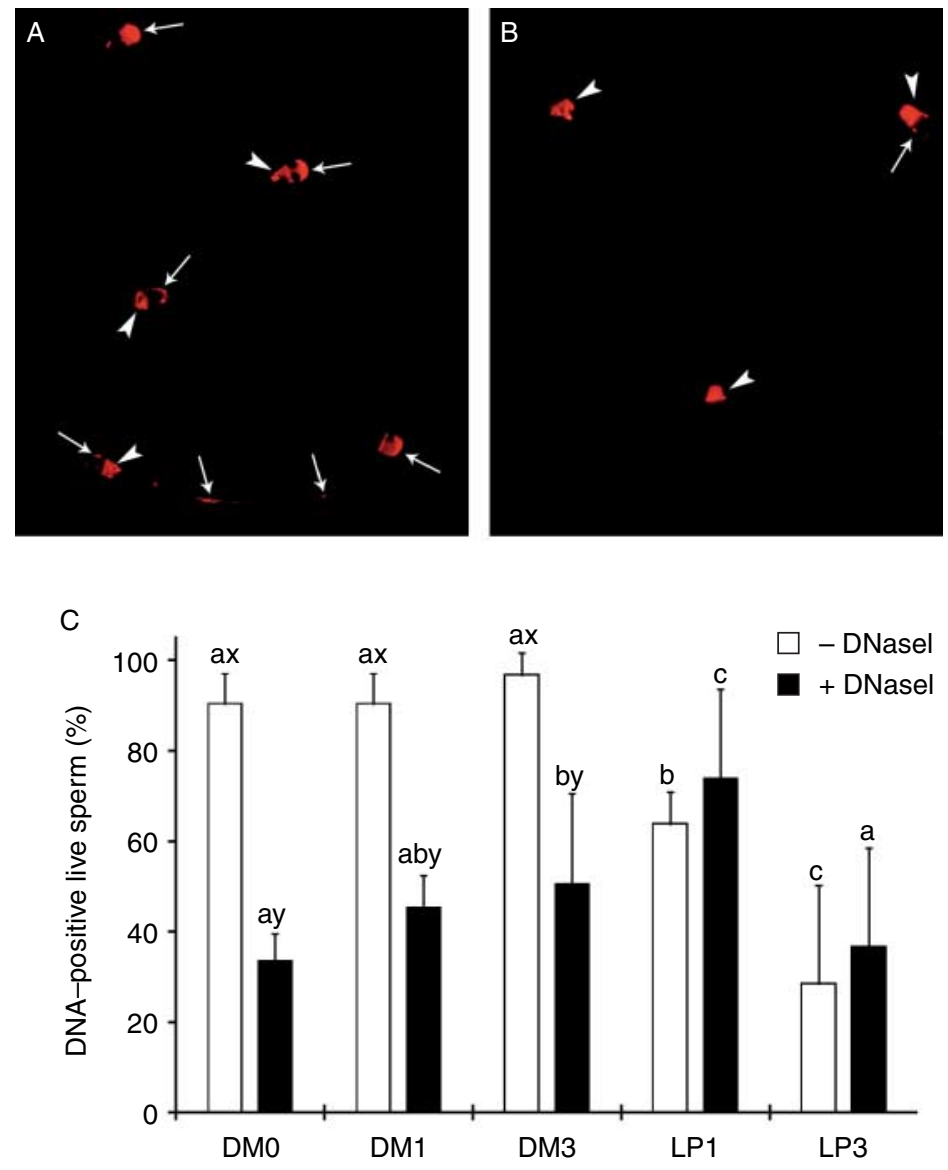

D

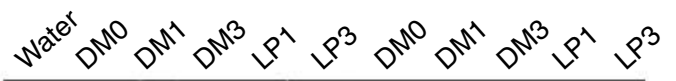

Supernatant (medium)

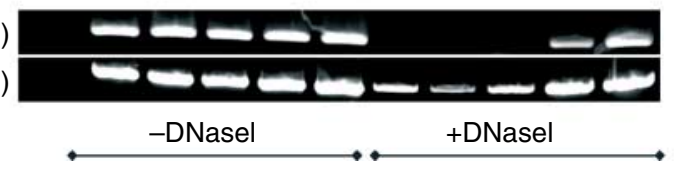

Figure 2 Effect of DNase treatment on DNA-sperm association. (A) Motile sperm co-incubated with 3\% DMSO and rhodamine-pGeneGrip-lacZ show discrete fluorescent dots in various locations (arrows) and occasionally uniform postacrosomal fluorescence (arrowheads). (B) DNase-treated sperm show uniform postacrosomal fluorescence (arrowheads). (C) Mean percentages ( \pm s.D.) of rhodamine-pGeneGrip-lacZ-labelled motile sperm with discrete fluorescent dots were quantified with (black bars) and without (white bars) DNase treatment under different conditions (0, 1, 3\% DMSO (DM) or 1, $3 \mu \mathrm{g}$ lipofectamine (LP)). Different letters denote significant differences $(P<0.05)$ within $\left({ }^{\mathrm{a}, \mathrm{b}, \mathrm{c}}\right)$ or between $\left.{ }^{\mathrm{x}, \mathrm{y}}\right)$ different DNase treatment groups ( \pm DNase). (D) Presence of pEGFP-C1 plasmid DNA in supernatant and sperm pellet following transfection under different conditions.

zygote generated strong target amplification (Fig. 3A). If the zygotes were to contain the plasmid intracellularly, this would have required the DNA-associated sperm to transfer the reporter plasmids into the oocyte cytoplasm after fusion with the oocyte plasma membrane.
To directly assess internalisation, sperm was incubated with fluorescently labelled DNA and used for IVF. To maximise the proportion of membrane-bound or fused sperm, thereby increasing the chances of detecting fluorescent label at the oocyte plasma membrane or in

Table 1 In vitro development of bovine embryos after IVF with sperm transfected with episomal (pEpi) or non-episomal (pMax-GFP) vectors under different conditions.

\begin{tabular}{|c|c|c|c|c|c|c|c|}
\hline Plasmid & Group & $n$ & $n I V C$ & $\geq 2$-Cell $(\%, \pm$ S.E.M.) & $\mathbf{B}^{1-3 a}(\%, \pm$ S.E.M. $)$ & $\begin{array}{c}\% B^{1-3 a} \text { of } \\
\text { cleaved } \pm \text { s.E.M. }\end{array}$ & PCR-positive $B^{1-3}$ \\
\hline \multirow[t]{4}{*}{ pEpi } & No DNA & 4 & 164 & $150(91.5 \pm 4.0)^{*}$ & $95(57.9 \pm 3.0)^{*}$ & $63.3 \pm 3.3^{*}$ & 0/95 \\
\hline & $\mathrm{DM} 3$ & 4 & 228 & $187(82.0 \pm 2.9)^{+}$ & $84(36.8 \pm 4.3)^{\dagger}$ & $44.9 \pm 4.7^{\dagger}$ & $0 / 84$ \\
\hline & LP1 & 4 & 215 & $176(81.9 \pm 5.2)^{\dagger}$ & $86(40.0 \pm 5.9)^{\dagger}$ & $48.9 \pm 5.8^{\dagger}$ & $0 / 86$ \\
\hline & $\mathrm{DM} 3 / \mathrm{LP} 1$ & 4 & 214 & $168(78.5 \pm 3.2)^{+}$ & $88(41.1 \pm 2.7)^{\dagger}$ & $52.4 \pm 4.3^{*,+}$ & $0 / 88$ \\
\hline \multirow[t]{4}{*}{ pMax-GFP } & No DNA & 6 & 345 & $312(90.4 \pm 1.5)^{*}$ & $188(54.5 \pm 2.5)^{*}$ & $60.3 \pm 2.6^{*}$ & $0 / 188$ \\
\hline & $\mathrm{DM} 3$ & 6 & 331 & $298(90.0 \pm 1.3)^{*}$ & $151(45.6 \pm 3.1)^{\dagger}$ & $50.7 \pm 4.1^{\dagger}$ & $0 / 151$ \\
\hline & LP1 & 6 & 347 & $287(82.7 \pm 4.5)^{\dagger}$ & $183(52.7 \pm 4.2)^{*,+}$ & $63.8 \pm 5.8^{*}$ & $0 / 183$ \\
\hline & $\mathrm{DM} 3 / \mathrm{LP} 1$ & 6 & 337 & $261(77.4 \pm 2.9)^{+}$ & $159(47.2 \pm 5.6)^{*,+}$ & $60.9 \pm 8.4^{*}$ & $0 / 159$ \\
\hline
\end{tabular}

$n$, number of independent IVF experiments; $\mathrm{B}^{1-3}$ were tested for the presence or expression of the GFP reporter by PCR or epifluorescence microscopy respectively; ${ }^{*, t}$ For each plasmid, rows with these different superscripts within a column differ significantly $(P<0.05)$. aproportion of the total number of embryos placed into IVC ( $n$ IVC) that developed into blastocysts (B) grades $1-3\left(B^{1-3}\right)$. 

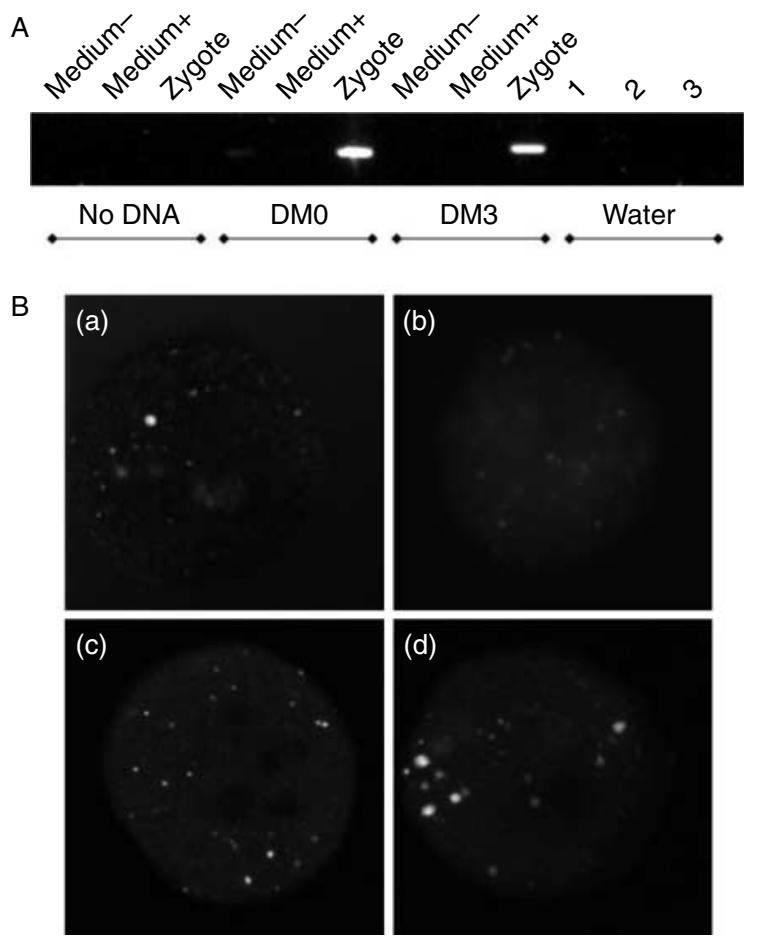

Figure 3 Presence of reporter DNA in IVF zygotes. (A) Oocytes were fertilised with non-transfected (control) or pEpi-transfected sperm (DM0 and DM3). One day post-fertilisation, culture medium with (+) or without (-) DNasel treatment and pools of 20 DNase-treated zygotes were analysed by PCR. No template controls ('water') were performed in triplicates ('1, 2 and 3'). (B) Zygotes were derived from zona-free IVF using sperm transfected with Cy3-labelled Label IT plasmid (positive control, a), Cy3-labelled pEpi (b), unlabelled pEpi (negative control 1, c) or non-transfected (negative control 2, d). Sperm were transfected under DM0 conditions. Zygotes were fixed 1 day postfertilisation, stained with Hoechst 33342, scored for the presence of two pronuclei (data not shown) and analysed by confocal microscopy. Complete confocal image stacks are shown in Z-projection.

the cytoplasm, we used zona-free oocytes for IVF. Indeed, zona-free IVF increased the rate of polyspermy as judged by the number of zygotes with either 1-2 vs $>2$ pronuclei $(250 / 290=86$ vs $7 / 290=2 \%, n=6$, for zona-intact controls and $132 / 176=75$ vs $12 / 176=7 \%$, $n=8$, for zona-free IVF respectively, $P<0.05)$. Zona-free zygotes were analysed by confocal microscopy and fertilisation confirmed by the presence of two pronuclei after Hoechst 33342 staining. No specific signal above background spots of auto-fluorescence was detected at the plasma membrane or in the cyto- or nucleoplasm of zygotes derived from Cy3-labelled pEpi $(n=60)$ or control IVF with Cy3-IT label only $(n=36)$ (Fig. 3B).

Following in vitro development and epifluorescence microscopy, no GFP-positive blastocysts were detected from oocytes fertilised with pEpi-transfected sperm $(n=156)$. Using a stringent PCR assay, no GFP reporter plasmid was detectable in any of the IVF blastocysts derived from sperm that were co-incubated with pEpi and pMax-GFP under DM3 $(n=84$ and $n=151$ respectively), LP1 $(n=86$ and $n=183$ respectively) or DM3/LP1 ( $n=88$ and $n=159$ respectively) conditions (Table 1).

\section{Transfecting zona-free embryos fertilised with DNA-associated sperm}

Since IVF with transfected sperm did not produce transgenic embryos, we sought to combine this treatment with direct transfection of bovine embryos. The zona pellucida was removed before in vitro-matured (IVM) or IVF and zona-free oocytes and embryos were cultured singularly in the presence of DNA. Compared with standard zona-intact group culture, cleavage and blastocyst development was significantly reduced in zonafree single-cultured embryos (Table 2). This reduction in development did not depend on whether the zona and surrounding cumulus corona was removed before IVM or IVF and might have partially contributed to the increased rate of polyspermy. Addition of DNA (DM0) and DMSO (DM3) or lipofectamine (LP1) during IVM or IVF and subsequent in vitro culture (IVC) did not further compromise development. Embryos obtained from both zona-free treatments were analysed for the presence of transgene by epifluorescence and subsequent PCR. None of the embryos analysed for GFP fluorescence were found positive ( $n=45$ and $n=49$ for zona-free IVM and IVF respectively; Table 2) compared with non-transfected controls. A subset of these was analysed by anti-GFP immunocytochemistry $(n=48)$ without detecting a positive signal (data not shown). As the reporter plasmid was continuously present during IVC, culture medium and individual embryos were extensively washed, incubated with DNase and analysed separately by PCR (Fig. 4A). Non-transfected embryos served as additional controls. No reporter DNA was detectable in the collected culture medium, ruling out false signals from carry-over contamination. Morulae and blastocysts from all three treatments were positive for the GFP transgene $(14 / 22=63,15 / 24=63$ and $9 / 22=40 \%$ for DM0, DM3 and LP1 respectively). Taken together, our results indicate the presence of the reporter DNA on or in bovine embryos but provide no evidence for its uptake.

\section{ICSI generates transgenic embryos expressing GFP}

To rule out the technical problems in expression or detection of GFP fluorescence, we performed several control experiments. The pEpi vector was strongly expressed after transient transfection into bovine embryonic fibroblasts $(115 / 554=20.8 \%$, data not shown). Following ICSI, the pEpi vector significantly reduced cleavage into 2-cell compared with noninjected and pDB2-injected controls (Table 3). However, blastocyst development from cleaved embryos was not affected and $18-25 \%$ of pEpi- and pDB2-injected 
Table 2 In vitro development of bovine embryos produced from zona-free oocytes cultured and transfected under different conditions.

\begin{tabular}{|c|c|c|c|c|c|c|c|c|c|}
\hline Transfection & $\begin{array}{l}\text { Zona-free } \\
\text { step }\end{array}$ & IVC & $n$ & $n I V C$ & $\begin{array}{c}\geq \text { 2-Cell } \\
(\%, \pm \text { s.E.M. })\end{array}$ & $\begin{array}{c}\mathbf{B}^{\mathbf{1 - 3 a}} \\
(\%, \pm \text { s.E.M. })\end{array}$ & $\begin{array}{c}\% B^{1-3 a} \text { of } \\
\text { cleaved } \pm \text { s.E.M. }\end{array}$ & $\begin{array}{c}\text { GFP-positive } \\
\text { B }^{1-3}\end{array}$ & $\begin{array}{c}\text { PCR-positive } \\
\text { M/B }^{1-3}(\%)\end{array}$ \\
\hline No & No & Group & 4 & 183 & $141(77.0 \pm 6.4)^{*}$ & $83(45.4 \pm 5.7)^{*}$ & $58.9 \pm 3.8^{*}$ & ND & ND \\
\hline No & IVM & Single & 5 & 162 & $79(48.8 \pm 6.2)^{\dagger}$ & $17(10.5 \pm 3.5)^{\dagger}$ & $21.5 \pm 11.3^{+}$ & $0 / 17$ & $0 / 17(0)$ \\
\hline DMO & IVM & Single & 4 & 104 & $61(58.7 \pm 4.4)^{+, \neq}$ & $8(7.7 \pm 1.8)^{\dagger}$ & $13.1 \pm 3.4^{+}$ & $0 / 8$ & $6 / 10(60)$ \\
\hline DM3 & IVM & Single & 5 & 165 & $123(74.5 \pm 6.4)^{*}$ & $26(15.8 \pm 3.7)^{+}$ & $21.1 \pm 4.5^{+}$ & $0 / 24$ & $7 / 12(58)$ \\
\hline LP1 & IVM & Single & 3 & 101 & $67(66.3 \pm 7.9)^{*, \neq}$ & $13(12.9 \pm 5.1)^{\dagger}$ & $19.4 \pm 8.0^{\dagger}$ & $0 / 13$ & $5 / 13(38)$ \\
\hline No & No & Group & 2 & 91 & $79(86.8 \pm 3.1)^{*}$ & $58(63.7 \pm 8.9) *$ & $73.4 \pm 7.6^{*}$ & ND & ND \\
\hline No & IVF & Single & 4 & 122 & $90(73.8 \pm 1.9)^{+}$ & $8(6.6 \pm 1.0)^{+}$ & $8.9 \pm 2.9^{+}$ & $0 / 8$ & $0 / 8(0)$ \\
\hline DMO & IVF & Single & 5 & 168 & $99(58.9 \pm 5.3)^{\ddagger}$ & $14(8.3 \pm 0.9)^{+}$ & $14.1 \pm 2.2^{+, \neq}$ & $0 / 14$ & $8 / 12(67)$ \\
\hline DM3 & IVF & Single & 4 & 160 & $114(71.3 \pm 6.3)^{t, \S}$ & $29(18.1 \pm 3.7)^{\ddagger}$ & $25.4 \pm 5.1^{\ddagger}$ & $0 / 29$ & $8 / 12(67)$ \\
\hline LP1 & IVF & Single & 2 & 62 & $41(66.1 \pm 7.1)^{\ddagger, \S}$ & $6(9.7 \pm 1.0)^{t, \neq}$ & $14.6 \pm 0.3^{\dagger, \neq}$ & $0 / 6$ & $4 / 9(44)^{b}$ \\
\hline
\end{tabular}

Sperm were transfected with pEpi under different conditions (0,3\% DMSO (DM) or $1 \mu \mathrm{g}$ lipofectamine (LP)). The zona pellucida was either left intact or removed before IVM or IVF respectively. Embryos were cultured in group (zona-intact control) or single IVC. $n$, number of independent experiments; $*,+, \neq, \S$ For each zona-free treatment, only rows with no common superscripts within a column differ significantly $(P<0.05)$. ND, not determined. ${ }^{a}$ Proportion of the total number of embryos placed into IVC ( $n$ IVC) that developed into blastocysts (B) grades $1-3$ (B ${ }^{1-3}$ ). ${ }^{b}$ Additional morulae $(M)$ grades 1-3 $\left(\mathrm{M}^{1-3}\right)$ were included in the analysis.

cleaved embryos were GFP positive (Table 3, Fig. 4B, C, $\mathrm{D}$ and $\mathrm{E})$, demonstrating uptake and expression of the reporter DNA.

\section{Discussion}

We have shown that due to the lack of DNA uptake into sperm, combining SMGT with IVF was an inefficient method to produce transgenic bovine embryos. Plasmid binding to the sperm surface, preferentially in the postacrosomal region, has been extensively documented (Spadafora 1998). In our experiments, almost all motile sperm associated with fluorescently labelled plasmid in a characteristic pattern of randomly localised discrete dots. Following DNase treatment, less than half of these sperm retained their fluorescent label. This reduction is in agreement with the previous studies using radioactively (Atkinson et al. 1991) or fluorescently labelled DNA (Carballada \& Esponda 2001). In the label-retaining sperm fraction, exogenous DNA was protected from DNase digestion, either via association with the sperm membrane or via internalisation. The former is a plausible possibility, given that the presence of liposomes was sufficient to protect plasmid DNA from degradation, both in a fluorescent and in a PCR-based assay. A similar protective effect has been observed with complexes of plasmid DNA and silk-polylysine molecules (Numata \& Kaplan 2010) and may be due to liposomes preventing DNase from access to the plasmid. The DNase-resistant signal was predominantly a uniform postacrosomal stain. This uniform stain was almost completely absent $(<5 \%)$ in live sperm but became apparent in $>99 \%$ of immotile sperm following freezethawing. We therefore interpreted this pattern as indicative of dead sperm. Our finding is consistent with a previous study where similar postacrosomal staining accounted for $>99 \%$ of labelling in coldshocked immotile sperm (Atkinson et al. 1991).

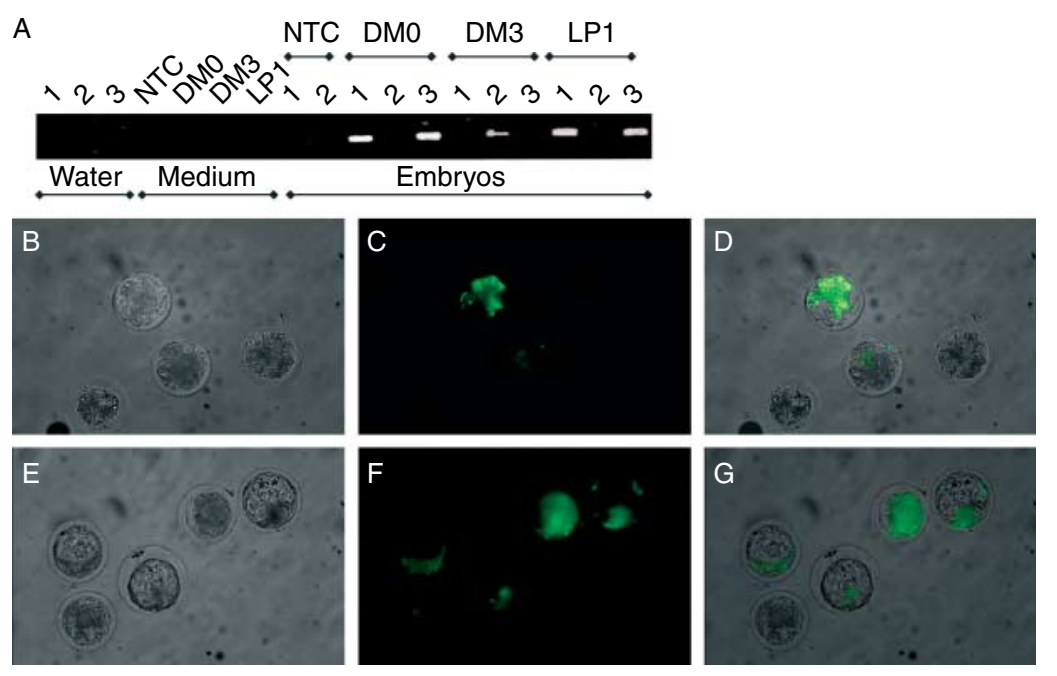

Figure 4 Presence of reporter DNA in transfected zonafree IVF and control ICSI embryos (A) Detection of pEpi in DM0, DM3 and LP1 blastocysts derived from zonafree IVF. All samples were washed and DNase treated before PCR. Non-transfected samples provide controls (NTC). Numbers indicate different individual embryos analysed. No template controls ('water') were performed in triplicates ('1, 2 and 3 '). (B, C, D, E, F and G) GFP expression in D7 embryos after ICSI with pEpi- (C) or pDB2-incubated sperm (F), corresponding bright field (B and $\mathrm{E}$ respectively) and merged images (D and $G$ respectively). 
Table 3 In vitro development of bovine embryos after ICSI transfected with episomal (pEpi) or non-episomal (pDB2) vectors.

\begin{tabular}{|c|c|c|c|c|c|c|}
\hline Group & $n$ & $n I V C$ & $\geq$ 2-Cell (\%, \pm S.E.M.) & $\mathbf{B}^{1-3 a}(\%, \pm$ S.E.M. $)$ & $\begin{array}{c}\mathbf{B}^{\mathbf{1 - 3}} \text { of cleaved } \\
(\%, \pm \text { s.E.M. })\end{array}$ & $\begin{array}{c}\text { GFP-positive embryos }^{\mathrm{b}} \\
(\%, \pm \text { s.E.M. })\end{array}$ \\
\hline No DNA & 3 & 68 & $52(76.4 \pm 4.2)^{*}$ & $15(22.1 \pm 4.6)$ & $28.8 \pm 7.5$ & - \\
\hline pEpi & 3 & 74 & $42(56.8 \pm 2.0)^{\dagger}$ & $12(16.2 \pm 4.1)$ & $28.6 \pm 8.0$ & $10(23.8 \pm 10.0)$ \\
\hline pDB2 & 3 & 65 & $48(73.8 \pm 5.8)^{*}$ & $13(20.0 \pm 4.8)$ & $27.1 \pm 5.1$ & $9(18.8 \pm 2.2)$ \\
\hline
\end{tabular}

$n$, number of independent experiments; ${ }^{*}{ }^{\dagger}$ Rows with these different superscripts within a column differ significantly $(P<0.05)$.

${ }^{a}$ Proportion of the total number of embryos placed into IVC ( $n$ IVC) that developed into blastocysts (B) grades $1-3$ ( $\mathrm{B}^{1-3}$ ). ${ }^{\mathrm{b}}$ Proportion of GFP-fluorescent embryos to total number of injected zygotes that developed into $\geq 2$-cell.

Despite this evidence for sperm-DNA association, it is still unclear whether and how exogenous DNA could cross the sperm plasma membrane. In principle, eukaryotic cells can take up DNA by direct transfer, carrier-mediated transfer or via transient membrane permeabilisation (Stephens \& Pepperkok 2001). We employed all three approaches in our experiments. Direct transfer via microinjection is technically challenging and low throughput but achieves transfer efficiencies and survival rates up to $100 \%$. We used this method to test the episomal reporter plasmid pEpi, as well as non-episomal control plasmids, by injecting them directly into oocytes. SMGT-ICSI produced green fluorescent embryos at various stages, confirming previous results that showed expression and episomal maintenance of the CMV-driven reporter gene in bovine blastocysts after oocytoplasmic injection (lqbal et al. 2009). Thus, the CMV promoter is not silenced in bovine pre-implantation stages, validating our use of CMV-driven reporter plasmids. Carrier-mediated transfer is comparatively simple, high throughput and does not require technically advanced equipment. It relies on coupling DNA to cell-permeable molecules, such as cationic liposomes, and piggybacking it into the cell (lipofection). The positive charge of the liposomes allows them to non-covalently interact with the negatively charged backbone of polynucleotides, forming lipoplexes. These then interact with the negatively charged plasma membrane, resulting in delivery to the target cells. Internalisation of the nucleic acids occurs primarily via endocytosis, rather than direct lipoplexplasma membrane fusion and translocation of genes into the cytosol (Pichon et al. 2010). Various endocytic pathways operate in eukaryotic cells and the relative contribution of clathrin-dependant and -independent lipoplex internalisation remains poorly defined (Pichon et al. 2010). Although internalisation is a necessary step for transfection to occur, it does not determine eventual transfection efficiency. This rather depends on the subsequent intracellular trafficking, namely escape of plasmid DNA from the endosome, cytosolic migration to the perinuclear space and nuclear import through the nuclear pores (Hoekstra et al. 2007). This entire cellular uptake mechanism is unlikely to operate efficiently in mature spermatozoa, which lack the intracellular organisation required for membrane trafficking, including endosomes, endoplasmic reticulum and Golgi apparatus (Fawcett 1975). What little cytoplasm exists in the sperm head is confined to small areas between the plasma and acrosome membrane, the acrosome and nuclear membrane (peri- and subacrosomal layers respectively), as well as the postacrosomal region (Toshimori 2009). Consequently, sperm are unable to endocytose a variety of exogenous tracers for fluid-phase or receptor-mediated endocytosis, even when those tracers clearly adsorbed to the spermatozoon cell surface (Oko et al. 1993). Putative DNA binding proteins have been described in sperm (Zani et al. 1995, Carballada \& Esponda 2001), but it is unclear whether these are identical to the membrane-associated glucosaminoglycans suggested as potential binding sites for lipoplexes (Mislick \& Baldeschwieler 1996). In addition to these general concerns regarding the efficacy of liposomes in mediating DNA uptake into sperm, lipofectamine interfered with the DNase protection assay. We could therefore not determine whether it affected DNA binding or uptake. Another reagent used for increasing DNA uptake is DMSO. This is thought to transiently permeabilise the membrane, allowing passive diffusion of DNA through the pores. In conjunction with cold- and heatshock treatment, this method has significantly increased DNA-sperm binding in mouse and rabbit IVF (Kuznetsov et al. 2000, Li et al. 2006, Shen et al. 2006). However, no effect on DNA-sperm binding or sperm viability was found in pig (Garcia-Vazquez et al. 2011). We also found no significant increase in DNA binding to DMSOtreated sperm. While the effect on initial cleavage was not consistent, bovine blastocyst development was significantly reduced after IVF with DMSO-treated sperm. This indicates some damaging effect of DMSO on sperm integrity and capacity to contribute towards normal development, similar to what has been described in fish (Liu et al. 1999). This damage could be alleviated by the inclusion of lipofectamine (DM3/LP1 in Table 1). As DMSO interacts electrostatically with phospholipid membranes (Anchordoguy et al. 1991), it may similarly bind liposomes, potentially neutralising its negative effect on the sperm plasma membrane. Such an interaction may increase clearance of DMSO-lipofectamine complexes into the surrounding mineral oil, minimising exposure to biological membranes.

For live sperm, we found no preference in DNA binding across the entire sperm surface. This is in contrast to other reports that have seen preferential binding to the 
postacrosomal region (Carballada \& Esponda 2001). This discrepancy may be due to the sensitivity of our method as well as difference in sperm viability. Fluorescently labelled plasmids appeared as discrete dots of variable size, similar to what has been observed after transfection of other eukaryotic cells (Watt et al. 2002). We estimate that sperm viability and motility was $>95 \%$ following DNA incubation and purification. This may account for the lack of postacrosomal staining described in other studies. In our hands, preferential localisation of fluorescent signal in the postacrosomal region was only evident in immotile sperm, in accordance with previous reports (Brackett et al. 1971, Atkinson et al. 1991). This postacrosomal signal was uniform and DNase resistant, indicating that it was of a different quality from the randomly localised, DNase-sensitive puncta in live sperm. We interpret this staining as non-specific signal uptake across the compromised plasma membrane of frozen-thawed sperm (Leahy \& Gadella 2011). Repeated freeze-thaw cycles would lead to lateral phase separation in the membrane, increasing its permeability and allowing leakage of labelled DNA or free Cy3 or rhodamine dye into the postacrosomal region, which comprises the major cytosolic compartment in the sperm head. Disrupting the sperm membrane by sonication also induced postacrosomal uptake in immature sperm that would otherwise not bind DNA (Carballada \& Esponda 2001).

Using sperm co-incubated with reporter plasmids for IVF, we initially found $>80 \%$ of all embryos producing the expected GFP band after genomic PCR. However, this signal was due to carry-over of plasmid from the sperm preparation into the IVC medium and disappeared after repeated washing and DNase treatment of the medium. Under such stringent detection conditions, we were unable to detect the transgene or GFP expression in 845 embryos screened. Using a GFP transgenic cell line carrying a single-copy integration of the GFP gene as control, we were able to amplify sufficient DNA from as little as seven to nine cells (data not shown). Thus, the negative results were unlikely due to low sensitivity of the genomic PCR method. Likewise, our ICSI control showed that the CMV reporter genes generated sufficient GFP fluorescence to be detectable from the 8-cell stage onwards. Our results are consistent with the previous reports failing to produce blastocysts containing or expressing the transgene following IVF with zona-intact oocytes (Brinster et al. 1989, Bachiller et al. 1991, Chan et al. 2000, Rieth et al. 2000, Pereyra-Bonnet et al. 2011).

In order to increase the chances of transfecting bovine embryos, we directly exposed them to naked DNA. Liposome-mediated DNA uptake into mouse oocytes and embryos has been previously reported (Carballada et al. 2000). In order to maximise transfection efficiency, we removed the zona pellucida before IVM or IVF. In both groups, cleavage and blastocyst development were significantly reduced in zona-free embryos cultured singularly to the blastocyst stage in the absence or presence of DNA. This reduction in development did neither depend on whether the zona and surrounding cumulus corona was removed before IVM or IVF, nor on whether DMSO or lipofectamine was added during IVC. Several reports have emphasised the importance of cumulus cells for IVM and IVF. Even though cumulusdenuded oocytes can complete meiotic maturation in vitro (Chian et al. 1994) and develop into fully developmentally competent blastocysts (Geshi et al. 2000), this occurs at much reduced efficiency. Therefore, it is generally accepted that cumulus cells are beneficial for IVM and developmental competence post-IVF (Tanghe et al. 2002). In our hands, between 8-16 and $7-18 \%$ of denuded zona-free oocytes and zygotes respectively developed into blastocysts. To our knowledge, this is the first demonstration of a chemically defined, cumulus- and zona pellucida-free In vitro production (IVP) system resulting in blastocyst development. Some of these blastocysts were morphologically suitable for embryo transfer (Robertson \& Nelson 1998) and their in vivo developmental potential remains to be determined. In contrast to a similar approach being successful in mouse embryos (Carballada et al. 2000), none of the bovine blastocysts that had been continuously exposed to the transgene for 8 days in vitro expressed detectable GFP protein. The only evidence that the transgene was present in embryos came from genomic PCR against the reporter plasmid after extensive washing and DNase treatment to minimise carry-over contamination from the IVM, IVF and IVC medium. Exogenous DNA, resistant to washing and inaccessible to DNase, was detectable in $63 \%$ of individual embryos, irrespective of whether DMSO was present or not. This may be due to extracellular incorporation or intracellular uptake of the reporter plasmid. Given the lack of reporter gene expression, we suggest that DNA present in the sperm preparation and culture medium may has simply been incorporated into the developing embryo and thereby become resistant to washing and DNase digestion. In this scenario, exogenous plasmid remains extracellular at all times. It first associates with the sperm plasma membrane before transferring to the oocyte membrane during fertilisation and sperm-oocyte fusion. As the embryo cleaves, it remains associated with the blastomere membrane and may be progressively protected from digestion during compaction and blastocyst formation, especially if it becomes located inside the developing embryo. Details of the sustained molecular interactions between DNA and the sperm, oocyte or embryo plasma membrane are presently unclear. However, we cannot rule out the alternative possibility that at low efficiency $(<1 / 845=0.002 \%)$ some sperm took up DNA, imported it into the nucleus, fertilised an oocyte and developed into an embryo capable of expressing integrated or extrachromosomal copies of the exogenous DNA. To distinguish between 
the two scenarios, it would be important to employ a combination of stringent assays demonstrating transgene uptake, integration and expression, such as electron microscopy, Southern blot, RT-qPCR and quantitative epifluorescence. In summary, the evidence and potential mechanism for spontaneous DNA uptake into live sperm or early embryos remains obscure.

Despite the lack of evidence for DNA uptake into sperm and subsequent transmission to oocytes and embryos in vitro, transgenic pigs have been repeatedly reported after using in utero insemination with 'transfected' sperm (Lavitrano et al. 2002, 2003, Manzini et al. 2006). The discrepancy to IVF results is unclear. It may perhaps be explained by uptake of the injected DNA into the embryo at some later developmental stage, resulting in genetically mosaic animals. We conclude that transfection methods that simply rely on incubating naked DNA with sperm or early embryos in vitro are of limited practical value for reliably and efficiently producing transgenic blastocysts and animals.

\section{Materials and Methods}

Chemicals were supplied by Sigma-Aldrich and all sperm and embryo manipulations were carried out at $38.5^{\circ} \mathrm{C}$ unless otherwise indicated.

\section{Plasmid preparation and labelling}

Several plasmids were used for co-incubation or co-injection with spermatozoa. Episomal vector pEpi (systematic designation pEPI-FGSARF, $7.1 \mathrm{~kb}$ ) is a non-viral self-replicating plasmid carrying enhanced GFP (EGFP) cDNA under regulation of a CMV promoter (Broll et al. 2010). It was used for all experiments throughout this study and owes its function to a S/MAR from the upstream border of the human IFN $\beta$ gene domain. Additionally, non-episomal reporter plasmids pGeneGrip-LacZ (8.5 kb, Genelantis, San Diego, USA), pEGFP-C1 (4.7 kb, Clontech), pEGFP-C1-based pDB2 (5 kb, Addgene plasmid 18954) and pMAX-EGFP (3.5 kb, Amaxa Biosystems, Cologne, Germany), all carrying their respective reporter genes under control of the CMV promoter, were used for monitoring DNA uptake into sperm, IVF embryos and ISCI embryos respectively. All plasmids were used in circular form, except for pEGFP-C1, which was digested with Sspl (Jena Bioscience, Jena, Germany) to give two fragments. The larger one $(4.1 \mathrm{~kb})$, containing the CMV-EGFP sequence, was purified with QIAquick-gel extraction kit (Qiagen) and used for transfection.

Plasmids were transformed into $\mathrm{DH} 5 \alpha$ competent cells and isolated using a PureLink HiPure Plasmid Filter Kit (Invitrogen). For fluorescence tracking experiments to monitor uptake into sperm or zygotes, plasmids were purchased either rhodamine labelled (pGeneGrip-LacZ, Genelantis) or Cy3 labelled using Mirus label IT tracker kit (Mirus, Madison, WI, USA) according to the manufacturer's instructions. Kit-provided Cy3-labeleld IT plasmid provided a positive control.

\section{Incubation of sperm with plasmid DNA}

In order to determine DNA binding, sperm were thawed, centrifuged at $700 \mathrm{~g}$ for $10 \mathrm{~min}$ and separated through a PureSperm gradient (45\%:90\%). The sperm pellet was washed twice in Hepes buffered Tyrode's albumin lactate pyruvate (TALP) medium and centrifuged at $200 \boldsymbol{g}$ for $10 \mathrm{~min}$ to remove cryoprotectant and sperm-DNA binding inhibitors (Carballada \& Esponda 2001). To induce cell death, one fraction of sperm was exposed to three freeze-thaw cycles in liquid nitrogen.

For transfection, motile and necrotic sperm $\left(1 \times 10^{6}\right.$ spermatozoa $/ \mathrm{ml}$ final concentration) were incubated at $37^{\circ} \mathrm{C}$ for 30 min with $1 \mu \mathrm{g}$ of each plasmid in i) $60 \mu \mathrm{l}$ TALP buffer (transfection reagent control or 'DMO') or in TALP buffer supplemented with ii) 1 or $3 \%$ (v/v) DMSO ('DM1 and DM3') or iii) 1 or $3 \mu \mathrm{l}$ lipofectamine 2000 (Life Technologies, Auckland, New Zealand; 'LP1 and LP3'). Before lipofection, the plasmid-liposome complex was incubated for $30 \mathrm{~min}$ at room temperature in $30 \mu \mathrm{ITALP}$, before it was added to $30 \mu \mathrm{l}$ of sperm-containing TALP medium. Sperm co-incubated without DNA and transfection reagents (transfection control) provided an additional control. Sperm prepared this way were either analysed directly or used for IVF.

\section{In vitro production of embryos}

IVM oocytes were derived from Holstein-Friesian dairy cows as described (Schurmann et al. 2006). IVM oocytes were fertilised at 20 to $22 \mathrm{~h}$ post-start of maturation as described previously (Thompson et al. 2000). Spermatozoa were prepared from commercially obtained frozen-thawed semen from a sire with proven fertility for IVF. The contents of two $0.25 \mathrm{ml}$ straws (containing $\sim 1 \times 10^{8}$ spermatozoa $/ \mathrm{ml}$ ) were layered upon a RediGrad gradient (45\%:90\%). Then motile spermatozoa were collected after centrifugation at $\sim 1200 \mathrm{~g}$ for $20 \mathrm{~min}$ at room temperature and washed twice in TALP and then incubated with pEpi or pMax-GFP $\left(1 \times 10^{6}\right.$ spermatozoa with $1 \mu \mathrm{g}$ plasmid in $60 \mu \mathrm{l}$ of fertilisation medium). Fertilisation was performed in $50 \mu \mathrm{l}$ IVF-SOF over a $24 \mathrm{~h}$ period as described (Schurmann et al. 2006). For IVC, ten embryos were pooled in $10 \mu \mathrm{l}$ ESOF medium (Wells et al. 2003) and cultured for 7 days (D0: fertilisation). On D5, embryos were changed into fresh LSOF drops containing $10 \mu \mathrm{M}$ 2, 4-dinitrophenol (Thompson et al. 2000). All cultures were overlaid with mineral oil and kept in a humidified modular incubation chamber (ICN Biomedicals, Inc., Aurora, OH, USA) gassed with $5 \% \quad \mathrm{CO}_{2}, 7 \% \quad \mathrm{O}_{2}$ and $88 \% \quad \mathrm{~N}_{2}$. Embryos were morphologically evaluated and classified as early blastocyst, blastocyst, late blastocyst and hatched blastocysts as described (Robertson \& Nelson 1998).

\section{Incubation of zona-free embryos with plasmid DNA}

The cumulus-corona was dispersed by vortexing oocytes in $500 \mu \mathrm{l}$ of $1 \mathrm{mg} / \mathrm{ml}$ bovine testicular hyaluronidase in $\mathrm{H} 199$ before or after 18-20 h of IVM, followed by three washes in $\mathrm{H} 199$ containing $0.1 \mathrm{mg} / \mathrm{ml}$ cold soluble polyvinyl acetate (PVA; 10-30 kDa; H199-PVA). The zona pellucida was either 
removed before IVM ('zona-free IVM') or before IVF ('zona-free IVF'). For both experimental groups, the zona was digested with pronase $(5 \mathrm{mg} / \mathrm{ml}$ in $\mathrm{H} 199)$ as described (Oback \& Wells 2003). For zona-free IVM, oocytes were matured individually in $5 \mu \mathrm{l}$ droplets of IVM medium. Mature zona-free oocytes were cultured individually in $5 \mu \mathrm{l}$ droplets of IVF medium and inseminated with $2 \times 10^{5}$ spermatozoa/ml as described (Misica-Turner et al. 2007). Following insemination for 18-24 h, embryos were cultured singularly in $5 \mu \mathrm{l}$ droplets of biphasic ESOF/LSOF as described (Oback \& Wells 2003). For zona-free IVF, the zona was removed from zona-intact mature oocytes just before fertilisation and embryos cultured as described earlier. When initial results with zona-free SMGT-IVF were negative, we supplemented IVM, IVF and IVC culture media with $20 \mathrm{ng} / \mu \mathrm{l}$ of pEpi plasmid to further increase the chance of DNA uptake into embryos during the entire IVP period.

\section{Production of embryos via ICSI}

Two straws of frozen sperm were thawed and washed twice in SP-TALP medium. One million sperm was incubated with $500 \mathrm{ng}$ pEpi or pDB2 at $37^{\circ} \mathrm{C}$ for $15 \mathrm{~min}$. The DNA-incubated spermatozoa of each experimental group were transferred into polyvinylpyrrolidone (catalog no. K-SIPV-200-5; Cook Medical, Brisbane, QLD, Australia) drops and immotile sperm injected into matured cumulus-free oocytes with an extruded first polar body. Oocytes were chemically activated (Shadanloo et al. 2010) and allowed to extrude the second polar body for $3 \mathrm{~h}$, before incubation in $2 \mathrm{mM}$ 6-dimethyl aminopurine for $4 \mathrm{~h}$ (Shadanloo et al. 2010). Immotile sperm without DNA incubation underwent the same chemical activation and served as sham control. Oocytes in all groups were washed in H199 plus $3 \mathrm{mg} / \mathrm{ml} \mathrm{BSA}$ and cultured in biphasic SOF (Tervit et al. 1972) for up to 8 days.

\section{DNAse protection assay}

Sperm samples co-incubated with plasmid DNA were washed three to five times in PBS, with centrifugation at $500 \mathrm{~g}$ for $5 \mathrm{~min}$ in between, before treating pellets and supernatant separately with or without five units of DNasel (Fermentas, Thermo Fisher Scientific, Auckland, New Zealand) at $37^{\circ} \mathrm{C}$ for $30 \mathrm{~min}$. Zygotes and embryos were washed three times in $35 \mathrm{~mm}$ dishes of PBS and treated with or without ten units of DNasel at $37^{\circ} \mathrm{C}$ for $1 \mathrm{~h}$. Following DNase treatment, samples were directly analysed by fluorescence microscopy (Olympus BX51, Japan) or used fresh (sperm) or after freezing (zygotes, embryos) at $-80{ }^{\circ} \mathrm{C}$ in $<2 \mu \mathrm{l}$ medium for PCR. Supernatant fractions from the last wash were transferred into a fresh tube for PCR. Sperm pellets were lysed in $10 \mathrm{mM}$ Tris- $\mathrm{HCl}, \mathrm{pH}$ 8.0, $100 \mathrm{mM} \mathrm{NaCl}, 1 \mathrm{mM}$ EDTA, $0.5 \%$ SDS and $2 \%$ mercaptoethanol at room temperature for $30 \mathrm{~min}$. Proteinase $\mathrm{K}$ (Invitrogen) at $200 \mu \mathrm{g} / \mathrm{ml}$ was added and incubated at $55^{\circ} \mathrm{C}$ for $2.5 \mathrm{~h}$. Pooled zygotes or individual embryos were transferred into $1 \times \mathrm{PCR}$ buffer, incubated with proteinase $\mathrm{K}(18 \mathrm{mg} / \mathrm{ml})$ at $55^{\circ} \mathrm{C}$ for $2 \mathrm{~h}$, followed by enzyme inactivation at $100{ }^{\circ} \mathrm{C}$ for $10 \mathrm{~min}$. For sperm pellets, DNA was isolated using phenol-chloroform extraction and resuspended in TE buffer. Concentration and purity were determined using a NanoDrop 1000 spectrophotometer (Thermo Fisher Scientific).

\section{PCR}

Supernatant fractions, DNA isolated from sperm, pooled zygotes and individual embryos were subjected to PCR analysis. PCR was performed in $25 \mu \mathrm{l}$ of volume containing equal amounts of template DNA, $1.5 \mathrm{mM} \mathrm{MgCl} 2,200 \mathrm{mM}$ dNTPs, $10 \mu \mathrm{M}$ primer and $2.5 \mathrm{U}$ Taq DNA polymerase. To minimise contamination and false-positive results, we used different primer sets to amplify EGFP from episomal and nonepisomal EGFP vectors. For pEpi, the amplicon went across the junction between the EGFP and S/MAR sequences ( $F, 5^{\prime}$-ATGGTGAGCAAGGGCGAGGAG-3' and R, 5' ${ }^{\prime}$-ATTACTTGTACAGCTCGTCCATG $-3^{\prime}$ ); for pEGFP-C1, both primer sites were located within the EGFP gene $\left(\mathrm{F}, 5^{\prime}\right.$-ATGGTCCTGCTGGAGTT $-3^{\prime}$ and $\mathrm{R}, 5^{\prime}$-TCCCCACACATCTCATGCT $-3^{\prime}$ ). These primer pairs detected 375 and $718 \mathrm{bp}$ amplicons and annealed at 59 and $55{ }^{\circ} \mathrm{C}$ respectively.

\section{Immunocytochemistry and epifluorescence microscopy}

Day 7 blastocysts were fixed in 4\% (w/v) paraformaldehyde/4\% $(\mathrm{w} / \mathrm{v})$ sucrose in PBS for $15 \mathrm{~min}$ at room temperature, washed three times in PBS, quenched in $50 \mathrm{mM} \mathrm{NH}_{4} \mathrm{Cl}$ in PBS for $10 \mathrm{~min}$, permeabilised in $0.1 \%(\mathrm{v} / \mathrm{v})$ Triton $\mathrm{X}-100$ in PBS for 10 min at room temperature and blocked in 5\% fatty acid-free BSA, 5\% FCS, in PBS for at least 30 min. Primary rabbit-anti-GFPantibody (1:2000, A-11122, Invitrogen) was applied overnight at $4{ }^{\circ} \mathrm{C}$, washed three times in blocking buffer (5\% BSA, 5\% FCS, in PBS) and incubated with Alexa Fluor 546 goat anti-mouse IgG (A-11030; 1:300; Life Technologies) secondary antibody for $30 \mathrm{~min}$ at $38.5^{\circ} \mathrm{C}$; both antibodies were diluted in blocking buffer. During secondary antibody incubation, DNA was counterstained with $5 \mu \mathrm{g} / \mathrm{ml}$ Hoechst 33342 (B-2261; $1 \mathrm{mg} / \mathrm{ml}$ in $\mathrm{H}_{2} \mathrm{O}$; Sigma). Embryos were washed three times in PBS and once in $\mathrm{H}_{2} \mathrm{O}$ before mounting (DAKO mounting medium; S3023; Dako Pty Ltd, Campbellfield, VIC, Australia) followed by assessment using an epifluorescence microscope (BX-50; Olympus Pty Ltd, Auckland, New Zealand) equipped with a Spot RT-KE slider CCD camera (Diagnostics Instruments Inc, Sterling Heights, MI, USA) and GFP filter block (excitation, $470 \pm 40 \mathrm{~nm}$; dichromat, LP 495; emission, 515 $30 \mathrm{~nm})$. Negative controls were processed the same way, except that the primary antibodies were replaced with blocking buffer.

\section{Statistical analysis}

All values are presented as mean \pm S.E.M., unless otherwise indicated. Statistical significance was accepted at $P<0.05$ and determined using ANOVA and Tukey's post hoc analysis for multiple mean comparisons with SAS v9.0 for sperm data (Figs 1 and 2). Embryo development data (Tables 1, 2 and 3) were analysed using both the two-tailed Fisher exact test for independence in $2 \times 2$ tables and the residual maximum likelihood method in GenStat (12th edition), with the treatments as fixed effects and experimental days as random effects. Both methods gave similar results. 


\section{Declaration of interest}

G Laible and B Oback are employees of AgResearch. $S$ Eghbalsaied was affiliated with AgResearch at the time of the study. This does not alter the author's adherence to all the journal's policies on sharing data and materials. There are no patents, products in development or marketed products to declare.

\section{Funding}

This project was funded by the Royan Institute and AgResearch Ltd. The authors thank Prof. J Bode for kindly donating the pEpi plasmid and S Tanhaee as well as Drs S Wagner, Y Khazaie and $\mathrm{K}$ Dormiani for plasmid propagation and fibroblast transfection.

\section{Acknowledgements}

They also thank F Shadanloo from the Royan Institute for help with ICSI.

\section{References}

Alderson J, Wilson B, Laible G, Pfeffer P \& L'Huillier P 2006 Protamine sulfate protects exogenous DNA against nuclease degradation but is unable to improve the efficiency of bovine sperm mediated transgenesis. Animal Reproduction Science 91 23-30. (doi:10.1016/j.anireprosci. 2005.03.005)

Anchordoguy TJ, Cecchini CA, Crowe JH \& Crowe LM 1991 Insights into the cryoprotective mechanism of dimethyl sulfoxide for phospholipid bilayers. Cryobiology 28 467-473. (doi:10.1016/0011-2240 (91)90056-T)

Anzar M \& Buhr MM 2006 Spontaneous uptake of exogenous DNA by bull spermatozoa. Theriogenology 65 683-690. (doi:10.1016/j.theriogenology.2005.06.009)

Atkinson PW, Hines ER, Beaton S, Matthaei KI, Reed KC \& Bradley MP 1991 Association of exogenous DNA with cattle and insect spermatozoa in vitro. Molecular Reproduction and Development 29 1-5. (doi:10.1002/mrd.1080290102)

Bachiller D, Schellander K, Peli J \& Ruther U 1991 Liposome-mediated DNA uptake by sperm cells. Molecular Reproduction and Development 30 194-200. (doi:10.1002/mrd.1080300305)

Brackett BG, Baranska W, Sawicki W \& Koprowski H 1971 Uptake of heterologous genome by mammalian spermatozoa and its transfer to ova through fertilization. PNAS 68 353-357. (doi:10.1073/pnas.68.2.353)

Brinster RL, Sandgren EP, Behringer RR \& Palmiter RD 1989 No simple solution for making transgenic mice. Cell 59 239-241. (doi:10.1016/ 0092-8674(89)90282-1)

Broll S, Oumard A, Hahn K, Schambach A \& Bode J 2010 Minicircle performance depending on S/MAR-nuclear matrix interactions. Journal of Molecular Biology 395 950-965. (doi:10.1016/j.jmb.2009. 11.066)

Canovas S, Gutierrez-Adan A \& Gadea J 2010 Effect of exogenous DNA on bovine sperm functionality using the sperm mediated gene transfer (SMGT) technique. Molecular Reproduction and Development 77 687-698. (doi:10.1002/mrd.21205)

Carballada R \& Esponda P 2001 Regulation of foreign DNA uptake by mouse spermatozoa. Experimental Cell Research 262 104-113. (doi:10.1006/excr.2000.5079)

Carballada R, Degefa T \& Esponda P 2000 Transfection of mouse eggs and embryos using DNA combined to cationic liposomes. Molecular Reproduction and Development 56 360-365. (doi:10.1002/1098-2795 (200007)56:3 <360::AID-MRD5 > 3.0.CO;2-8)

Chan AW, Luetjens CM, Dominko T, Ramalho-Santos J, Simerly CR, Hewitson L \& Schatten G 2000 Foreign DNA transmission by ICSI: injection of spermatozoa bound with exogenous DNA results in embryonic GFP expression and live rhesus monkey births. Molecular Human Reproduction 6 26-33. (doi:10.1093/molehr/6.1.26)

Chian RC, Niwa K \& Sirard MA 1994 Effects of cumulus cells on male pronuclear formation and subsequent early development of bovine oocytes in vitro. Theriogenology 41 1499-1508. (doi:10.1016/0093691X(94)90201-S)

Fawcett DW 1975 The mammalian spermatozoon. Developmental Biology 44 394-436. (doi:10.1016/0012-1606(75)90411-X)

Gagne MB, Pothier F \& Sirard MA 1991 Electroporation of bovine spermatozoa to carry foreign DNA in oocytes. Molecular Reproduction and Development 29 6-15. (doi:10.1002/mrd.1080290103)

Gandolfi F, Terqui M, Modina S, Brevini TA, Ajmone-Marsan P, FoulonGauze F \& Courot M 1996 Failure to produce transgenic offspring by intra-tubal insemination of gilts with DNA-treated sperm. Reproduction, Fertility, and Development 8 1055-1060. (doi:10.1071/RD9961055)

Garcia-Vazquez FA, Garcia-Rosello E, Gutierrez-Adan A \& Gadea J 2009 Effect of sperm treatment on efficiency of EGFP-expressing porcine embryos produced by ICSI-SMGT. Theriogenology 72 506-518. (doi:10. 1016/j.theriogenology.2009.04.006)

Garcia-Vazquez FA, Ruiz S, Grullon LA, de Ondiz A, Gutierrez-Adan A \& Gadea J 2011 Factors affecting porcine sperm mediated gene transfer. Research in Veterinary Science 91 446-453. (doi:10.1016/j.rvsc.2010. 09.015)

Geshi M, Takenouchi N, Yamauchi N \& Nagai T 2000 Effects of sodium pyruvate in nonserum maturation medium on maturation, fertilization, and subsequent development of bovine oocytes with or without cumulus cells. Biology of Reproduction 63 1730-1734. (doi:10.1095/ biolreprod63.6.1730)

Giovannoni R, Vargiolu A, Manzini S, De Cecco M, Seruggia D, Busnelli M, Grazia Cerrito M, Smolenski RT, Forni M, Bacci ML et al. 2010 CMVbased episomal vector is progressively lost in vivo in multi-gene transgenic pigs produced by SMGT. Transgenic Research 19330. (doi:10.1007/s11248-010-9366-9)

Hoekstra D, Rejman J, Wasungu L, Shi F \& Zuhorn I 2007 Gene delivery by cationic lipids: in and out of an endosome. Biochemical Society Transactions 35 68-71. (doi:10.1042/BST0350068)

Hoelker M, Mekchay S, Schneider H, Bracket BG, Tesfaye D, Jennen D, Tholen E, Gilles M, Rings F, Griese J et al. 2007 Quantification of DNA binding, uptake, transmission and expression in bovine sperm mediated gene transfer by RT-PCR: effect of transfection reagent and DNA architecture. Theriogenology 67 1097-1107. (doi:10.1016/ j.theriogenology.2006.12.011)

Iqbal K, Barg-Kues B, Broll S, Bode J, Niemann H \& Kues W 2009 Cytoplasmic injection of circular plasmids allows targeted expression in mammalian embryos. Biotechniques 47 959-968. (doi:10.2144/ 000113270)

Jenke AC, Scinteie MF, Stehle IM \& Lipps HJ 2004a Expression of a transgene encoded on a non-viral episomal vector is not subject to epigenetic silencing by cytosine methylation. Molecular Biology Reports 31 85-90. (doi:10.1023/B:MOLE.0000031363.35839.46)

Jenke AC, Stehle IM, Herrmann F, Eisenberger T, Baiker A, Bode J, Fackelmayer FO \& Lipps HJ 2004b Nuclear scaffold/matrix attached region modules linked to a transcription unit are sufficient for replication and maintenance of a mammalian episome. PNAS 101 11322-11327. (doi:10.1073/pnas.0401355101)

Kang JH, Hakimov H, Ruiz A, Friendship RM, Buhr M \& Golovan SP 2008 The negative effects of exogenous DNA binding on porcine spermatozoa are caused by removal of seminal fluid. Theriogenology 70 1288-1296. (doi:10.1016/j.theriogenology.2008.06.011)

Kim TS, Lee SH, Gang GT, Lee YS, Kim SU, Koo DB, Shin MY, Park CK \& Lee DS 2010 Exogenous DNA uptake of boar spermatozoa by a magnetic nanoparticle vector system. Reproduction in Domestic Animals 45 e201-e206. (doi:10.1111/j.1439-0531.2008.01128.x)

Kuznetsov AV \& Kuznetsova IV 1995 The binding of exogenous DNA pRK31acZ by rabbit spermatozoa, its transfer to oocytes and expression in preimplantation embryos. Ontogenez 26 300-309.

Kuznetsov AV, Kuznetsova IV \& Schit IY 2000 DNA interaction with rabbit sperm cells and its transfer into ova in vitro and in vivo. Molecular Reproduction and Development 56 292-297. (doi:10.1002/(SICI)10982795(200006)56:2 + <292::AID-MRD18>3.0.CO;2-Z) 
Lai L, Sun Q, Wu G, Murphy CN, Kuhholzer B, Park KW, Bonk AJ, Day BN \& Prather RS 2001 Development of porcine embryos and offspring after intracytoplasmic sperm injection with liposome transfected or non-transfected sperm into in vitro matured oocytes. Zygote 9 339-346. (doi:10.1017/S0967199401001393)

Lavitrano M, Camaioni A, Fazio VM, Dolci S, Farace MG \& Spadafora C 1989 Sperm cells as vectors for introducing foreign DNA into eggs: genetic transformation of mice. Cell 57 717-723. (doi:10.1016/00928674(89)90787-3)

Lavitrano M, Bacci ML, Forni M, Lazzereschi D, Di Stefano C, Fioretti D, Giancotti P, Marfe G, Pucci L, Renzi L et al. 2002 Efficient production by sperm-mediated gene transfer of human decay accelerating factor (hDAF) transgenic pigs for xenotransplantation. PNAS 99 14230-14235. (doi:10.1073/pnas.222550299)

Lavitrano M, Forni M, Bacci ML, Di Stefano C, Varzi V, Wang H \& Seren E 2003 Sperm mediated gene transfer in pig: selection of donor boars and optimization of DNA uptake. Molecular Reproduction and Development 64 284-291. (doi:10.1002/mrd.10230)

Leahy T \& Gadella BM 2011 Sperm surface changes and physiological consequences induced by sperm handling and storage. Reproduction 142 759-778. (doi:10.1530/REP-11-0310)

Li L, Shen W, Min L, Dong H, Sun Y \& Pan Q 2006 Human lactoferrin transgenic rabbits produced efficiently using dimethylsulfoxide-spermmediated gene transfer. Reproduction, Fertility, and Development 18 689-695. (doi:10.1071/RD06001)

Liu XY, Zohar Y \& Knibb W 1999 Association of foreign DNA with sperm of gilthead seabream, Sparus aurata, after sonication, freezing, and dimethyl sulfoxide treatments. Marine Biotechnology 1 175-183. (doi:10.1007/PL00011765)

Manzini S, Vargiolu A, Stehle IM, Bacci ML, Cerrito MG, Giovannoni R, Zannoni A, Bianco MR, Forni M, Donini P et al. 2006 Genetically modified pigs produced with a nonviral episomal vector. PNAS 103 17672-17677. (doi:10.1073/pnas.0604938103)

Misica-Turner PM, Oback FC, Eichenlaub M, Wells DN \& Oback B 2007 Aggregating embryonic but not somatic nuclear transfer embryos increases cloning efficiency in cattle. Biology of Reproduction $\mathbf{7 6}$ 268-278. (doi:10.1095/biolreprod.106.050922)

Mislick KA \& Baldeschwieler JD 1996 Evidence for the role of proteoglycans in cation-mediated gene transfer. PNAS 93 12349-12354. (doi:10.1073/ pnas.93.22.12349)

Numata K \& Kaplan DL 2010 Silk-based gene carriers with cell membrane destabilizing peptides. Biomacromolecules 11 3189-3195. (doi:10.1021/ bm101055m)

Oback B \& Wells DN 2003 Cloning cattle. Cloning and Stem Cells 5 243-256. (doi:10.1089/153623003772032763)

Oko R, Hermo L, Chan PT, Fazel A \& Bergeron JJ 1993 The cytoplasmic droplet of rat epididymal spermatozoa contains saccular elements with Golgi characteristics. Journal of Cell Biology 123 809-821. (doi:10.1083/jcb.123.4.809)

Osada T, Toyoda A, Moisyadi S, Akutsu H, Hattori M, Sakaki Y \& Yanagimachi R 2005 Production of inbred and hybrid transgenic mice carrying large $(>200 \mathrm{~kb})$ foreign DNA fragments by intracytoplasmic sperm injection. Molecular Reproduction and Development 72 329-335. (doi:10.1002/mrd.20319)

Pereyra-Bonnet F, Fernandez-Martin R, Olivera R, Jarazo J, Vichera G, Gibbons A \& Salamone D 2008 A unique method to produce transgenic embryos in ovine, porcine, feline, bovine and equine species. Reproduction, Fertility, and Development 20 741-749. (doi:10.1071/ RD07172)

Pereyra-Bonnet F, Gibbons A, Cueto M, Sipowicz P, Fernandez-Martin R \& Salamone D 2011 Efficiency of sperm-mediated gene transfer in the ovine by laparoscopic insemination, in vitro fertilization and ICSI. Journal of Reproduction and Development 57 188-196. (doi:10.1262/ jrd.10-063A)

Perry AC, Wakayama T, Kishikawa H, Kasai T, Okabe M, Toyoda Y \& Yanagimachi R 1999 Mammalian transgenesis by intracytoplasmic sperm injection. Science 284 1180-1183. (doi:10.1126/science.284. 5417.1180)
Pichon C, Billiet L \& Midoux P 2010 Chemical vectors for gene delivery: uptake and intracellular trafficking. Current Opinion in Biotechnology 21 640-645. (doi:10.1016/j.copbio.2010.07.003)

Rieth A, Pothier F \& Sirard MA 2000 Electroporation of bovine spermatozoa to carry DNA containing highly repetitive sequences into oocytes and detection of homologous recombination events. Molecular Reproduction and Development 57 338-345. (doi:10.1002/1098-2795(200012) 57:4<338::AID-MRD5 > 3.0.CO;2-K)

Robertson I \& Nelson R 1998 Certification and identification of the embryo. In Manual of the International Embryo Transfer Society, pp 103-134.

Schurmann A, Wells DN \& Oback B 2006 Early zygotes are suitable recipients for bovine somatic nuclear transfer and result in cloned offspring. Reproduction 132 839-848. (doi:10.1530/REP-06-0054)

Shadanloo F, Najafi MH, Hosseini SM, Hajian M, Forouzanfar M, Ghaedi K, Abedi P, Ostadhosseini S, Hosseini L, Eskandari-Nasab MP et al. 2010 Sperm status and DNA dose play key roles in sperm/ICSImediated gene transfer in caprine. Molecular Reproduction and Development 77 868-875. (doi:10.1002/mrd.21228)

Shen W, Li L, Pan Q, Min L, Dong H \& Deng J 2006 Efficient and simple production of transgenic mice and rabbits using the new DMSO-sperm mediated exogenous DNA transfer method. Molecular Reproduction and Development 73 589-594. (doi:10.1002/mrd.20401)

Spadafora C 1998 Sperm cells and foreign DNA: a controversial relation. BioEssays: News and Reviews in Molecular, Cellular and Developmental Biology 20 955-964. (doi:10.1002/(SICl)1521-1878(199811) 20:11<955::AID-BIES11>3.0.CO;2-8)

Stephens DJ \& Pepperkok R 2001 The many ways to cross the plasma membrane. PNAS 98 4295-4298. (doi:10.1073/pnas.081065198)

Tanghe S, Van Soom A, Nauwynck H, Coryn M \& de Kruif A 2002 Minireview: functions of the cumulus oophorus during oocyte maturation, ovulation, and fertilization. Molecular Reproduction and Development 61 414-424. (doi:10.1002/mrd.10102)

Tervit HR, Whittingham DG \& Rowson LE 1972 Successful culture in vitro of sheep and cattle ova. Journal of Reproduction and Fertility 30 493-497. (doi:10.1530/jrf.0.0300493)

Thompson JG, McNaughton C, Gasparrini B, McGowan LT \& Tervit HR 2000 Effect of inhibitors and uncouplers of oxidative phosphorylation during compaction and blastulation of bovine embryos cultured in vitro. Journal of Reproduction and Fertility 118 47-55. (doi:10.1530/reprod/118.1.47)

Toshimori K 2009 In Dynamics of the Mammalian Sperm Head: Modifications and Maturation Events From Spermatogenesis to Egg Activation. Berlin, Heidelberg: Springer.

Watt V M-A, Duzeski J, Loomis A, Machnik K, Noble M, Sebestyen M \& Hagstrom J 2002. Intracellular localization and expression of labeled plasmid DNA using label IT Tracker ${ }^{\mathrm{TM}}$ nucleic acid labeling kits. In Mirus Technical Report.

Webster NL, Forni M, Bacci ML, Giovannoni R, Razzini R, Fantinati $\mathbf{P}$, Zannoni A, Fusetti L, Dalpra L, Bianco MR et al. 2005 Multi-transgenic pigs expressing three fluorescent proteins produced with high efficiency by sperm mediated gene transfer. Molecular Reproduction and Development 72 68-76. (doi:10.1002/mrd.20316)

Wells DN, Laible G, Tucker FC, Miller AL, Oliver JE, Xiang T, Forsyth JT, Berg MC, Cockrem K, L'Huillier PJ et al. 2003 Coordination between donor cell type and cell cycle stage improves nuclear cloning efficiency in cattle. Theriogenology 59 45-59. (doi:10.1016/S0093-691X(02)01273-6)

Wu Y, Liu CJ, Wan PC, Hao ZD \& Zeng SM 2009 Factors affecting the efficiency of producing porcine embryos expressing enhanced green fluorescence protein by ICSI-mediated gene transfer method. Animal Reproduction Science 113 156-166. (doi:10.1016/j.anireprosci.2008. 08.014)

Zani M, Lavitrano M, French D, Lulli V, Maione B, Sperandio S \& Spadafora C 1995 The mechanism of binding of exogenous DNA to sperm cells: factors controlling the DNA uptake. Experimental Cell Research 217 57-64. (doi:10.1006/excr.1995.1063)

Received 3 September 2012

First decision 1 October 2012

Accepted 8 November 2012 